\title{
The Effect of Corruption Distance and Market Orientation on the Ownership Choice of MNEs: Evidence from China
}

\author{
Jing-Lin Duanmu* \\ School of Management \\ University of Surrey \\ UK GU2 7XH \\ j.duanmu@surrey.ac.uk
}

\begin{abstract}
:
Motivated by previous studies on the effect of corruption on entry strategies of Multinational Enterprises (MNEs), this research examines how corruption distance influences the choice between wholly owned subsidiary (WOS) and joint venture (JV) for MNEs operating in China. We found that MNEs from countries which are less corrupt than China prefer WOS over JV; the higher corruption distance it is between these countries and China, the higher probability their MNEs choose WOS over JV. In contrast, MNEs from equally and more corrupt countries do not prefer WOS over JV; nor the corruption distance affect their entry mode decision. Market orientation has a universal and powerful effect on the entry mode choice regardless which group of countries MNEs are from. It also weakens the tendency for MNEs from less corrupt countries to choose WOS over JV.
\end{abstract}

Key words: Corruption distance, Market orientation, Ownership choice, MNEs, China.

\footnotetext{
* Corresponding author: School of Management, University of Surrey, Guildford, Surrey, GU2

7XH, United Kingdom. Tel: +44(0)1483686342; Fax: +44(0)1483689511
} 


\section{The Effect of Corruption Distance and Market Orientation on the Ownership Choice of MNEs: Evidence from China}

\section{Introduction}

The appropriate ownership of productive enterprise is a central issue in economic theory and a practical question for multinational enterprises (MNEs) establishing new foreign affiliates. With the unprecedented acceleration of worldwide foreign direct investment (FDI), the question has become the object of considerable study (Johnson and Paul, 1975; Anderson and Gatignon, 1986; Dunning, 1995, etc). Among various entry mode choices, the wholly owned subsidiary (WOS) and the joint venture (JV) are the most important and complex investment forms compared to contract-based entry modes (Zhao, et al, 2004). The choice between WOS and JV has been subject to extensive empirical investigations (see a summary by Morschett, et al., 2010). Factors such as transaction cost related characteristics, international experience of the MNE, and cultural distance between the investing country and the host country have been found to have an impact on the choice. We focus here on another important issue: the impact of corruption distance on the choice between WOS and JV.

Corruption, roughly defined as the abuse of public office for private gain, has generated an immense literature (Lambert-Mogiliansky, et al, 2007). It is found to inhibit economic growth (Mauro, 1995), reduce the legitimacy of government (Anderson and Tverdova, 2003), and affect political and societal stability (Abed and Gupta, 2002). Although both developed and developing countries have various degrees of corruption, the problem of corruption is generally more prevalent in developing countries for a variety of political, societal and cultural reasons (Monte and Papagni, 2007). In many developing nations, business ventures require a large number of official approvals, usually in the form of licences or permits, to operate. This provides government officials with the opportunity to 
reap private benefits at the cost of institutional and social efficiency. Foreign direct investment (FDI) into developing countries is a pertinent case where entry and operations are commonly subject to extensive official scrutiny. Although most developing country governments see attracting FDI as an important policy priority, inefficient bureaucratic procedures and corrupt government officials remain sufficiently widespread to discourage international ventures.

Motivated by previous studies, we attempt to explore the effect of corruption distance on the ownership choice of MNEs operating in China. Our study departs from the existing literature in two principal respects. First, we propose that the direction of corruption distance matters. That is, relative to a given host country, MNEs from more corrupt and less corrupt countries may react differently to corruption in the host environment. Second, we study whether corruption distance between the host and home country of MNE increases the preference of WOS over JV. In addition, we investigate whether MNEs establishing local market oriented affiliates and those establishing export oriented affiliates react to corruption distance differently. Current literature on the relationship between corruption and ownership choice has not considered this issue. But recent FDI studies have found that local market oriented FDI (also called horizontal FDI) and export-oriented FDI (also called vertical FDI) tend to be motivated by very different factors (e.g. Markusen and Maskus 2002). Therefore, horizontal FDI and vertical FDI may have different responses to the host country institutional attributes such as the relative level of corruption in the host environment. Last but not least, we assess whether corruption distance and market orientation interact with each other in the process of entry mode decision.

China has become one of the top FDI recipient countries in the world; yet surprisingly limited research has been conducted to understand whether and how corruption in China affects entry strategies of MNEs. The rapid economic development that China has achieved so far by no means suggests that corruption is diminishing in this country. Instead, some scholars are concerned that corruption in China is becoming systemic (Root, 1996; Cheung, 1996). While there might be a host range of issues affected by 
corruption, we attempt to provide one of the first empirical investigations on the impact of corruption distance on the choice of entry mode of MNEs in China. This is a question of both empirical and practical significance to researchers, policy makers and MNEs in China. FDI regulations in China have long geared towards macroeconomic goal of promoting technology transfer and market competition. Therefore, policy makers may like to know how the relative corruption level in China affects the ownership structure of FDI projects because the structure affects the incentives of the foreign investors to apply their resources to the project, the degree of technology transfer, and the distribution of gains from FDI. For MNEs, ownership structure has a fundamental effect on how they allocate and control resources, coordinate with other parts of the corporation, and the prosperity of their operation in the host country.

The remainder of the paper is organized as follows. We review the literature on corruption and its impact on the global expansion of MNEs in section 2. This in turn motivates the key hypotheses of the paper. We then introduce our empirical strategy in section 3. Empirical results are reported in section 4. Finally, we discuss and conclude the paper in section 5 . 


\section{Literature review}

\subsection{Literature on corruption and FDI}

The effect of corruption on FDI has long been studied. There are different theoretical arguments suggesting a positive or negative effect of corruption on FDI. Habib and Zurawicki (2002) suggest that while foreign investors may shun corruption because they believe it is morally wrong (that is, on ethical grounds), they also may try to avoid corruption because it makes local operations risky, difficult to manage, and costly (that is, on economic grounds). Aizenman and Spiegel (2006) instead find that multinationals avoid corruption because of stringent home country laws. For instance, the Foreign Corrupt Practices Act of 1977, which forbids bribery by American multinationals, put US firms at a competitive disadvantage by seeking to prohibit their involvement in corrupt practices abroad. There are also posited both 'grabbing hand' and 'helping hand' effects, where it is acknowledged that bribery is costly for firms (Murphy, Shleifer, and Vishny, 1991; Boycko, Sheifer and Vishny, 1995) but it may also 'grease the wheels' of commerce, especially in the presence of pre-existing government failures (Kaufmann and Wei, 1999). It then becomes an empirical question which effect is dominant.

The empirical evidence on corruption suggests a prevailing negative impact on FDI (Habib and Zurawicki, 2002; Aizenman and Spiegel, 2006). While such evidence is not surprising, Egger and Winner (2006) revealed a more complex relationship between corruption and FDI. They found that although corruption is negatively correlated with FDI, the effect is neither uniform across countries nor uniform over time. Corruption, in their panel data analysis, was found to be important for intra-OECD FDI, but not for extra-OECD FDI. They speculated that this is because most FDI in OECD countries is horizontal. For non-OECD, developing countries where most FDI is vertical, 'classical' locational advantages such as low wages and production costs were found to overwhelm the impact of corruption. They found in addition that the negative impact of corruption has declined over time. In a similar vein, Hakkala, et al (2005) directly differentiated horizontal and vertical Swedish FDI in their investigation and found that although 
corruption reduces the probability that a Swedish firm will invest in a country in general, once a decision is made to enter, corruption reduces horizontal FDI but has no significant impact on vertical FDI. This demonstrates the different reactions of horizontal and vertical FDI to the corruption in the host country and suggests the insufficiency of treating FDI as a homogenous phenomenon.

The relationship between corruption and ownership choice has received less attention in the literature. One of the earliest attempts is Smarzynska and Wei (2002). In their crosssectional analysis of FDI in Eastern Bloc countries, high corruption of the host country leads to a preference of JV over WOS (see Table 1 for its methodological details). They interpreted that the choice of a lower level of ownership helps to reduce the commitment and associated risk in the invested projects and is a sensible reaction the Eastern Bloc countries which were quite unstable, risky and in transition environment in 1995. Their specific empirical context makes it tentative whether the result can be replicated in other countries. In contrast, Asiedu and Esfahani (2000) did not detect any significant impact of corruption on the choice between WOS and JV for US MNEs. But their exclusive data of overseas affiliates of US MNEs may limit the generalization of their result. In addition, none of the studies have differentiated between vertical and horizontal FDI in their investigation.

Different from other studies on corruption, Tekin-Koru (2006) probably provided the only study that focused on the impact of 'corruption distance' on entry mode strategy of MNEs. It is found that a higher corruption distance between the host country Turkey and home country leads to a preference for WOS relative to JV. The author argued that such reaction of MNEs in Turkey is theoretically sensible because Turkey, different from Eastern Bloc countries, has hosted foreign investments from Western Europe for a long time and had its trade and financial liberalization years before. Its stable environment could have reduced the importance of having a local partner. While providing interesting insights into the entry mode choice of MNEs in Turkey, one of the evident deficiencies of the research is that it did not take the direction of corruption distance into account. By using the absolute corruption distance in the investigation, it assumes away the potential 
relevance of direction of corruption distance. To sum up, the research on how corruption affects the entry strategy of MNEs is still in its infancy; more research is needed to understand when and how corruption influences entry strategies of MNEs.

The goal of our research is threefold. First we examine possible boundaries to TekinKoru's (2006) findings concerning corruption distance and mode of entry. We propose that the direction of corruption distance matters. A simple example may illuminate its important relevance. We take The Corruption Perception Index of 2009 by the Transparency International for example as it is a publically assessable data. The index shows that, on one hand, China scored 3.6 out of full score 10. The most corrupt country according to this index is Somalia which scored only 1.1. Therefore, the corruption distance between China and Somalia is 2.5. On the other hand, according to the index, Israel scored 6.1, which means that the corruption distance between Israel and China is also 2.5, but with important difference from that of Somalia. If we ignore the direction of corruption distance, and focus solely on the absolute value, we would assume that Israel investors will react to the corruption level in China in a same way as those from Somalia. This assumption is precarious and warrants a systematic investigation. Second, we will examine whether the corruption distance further influences the choice between WOS and JV. Third, we will assess how market orientation influences the choice between WOS and JV, and whether it also has a second order effect on entry mode choice by interacting with corruption distance. We present our hypotheses development in section 2.2.

\subsection{Hypotheses development}

The literature has inspired us to infer how the direction of corruption distance influences MNEs' entry strategies from different perspectives. First, firms from different institutional environment may develop different range of skills and competence to be able to survive and prosper in the environment. From resource dependency perspective (Pfeffer and Salancik, 1978), for a relatively corrupt host country, foreign investors from less corrupt countries may have motivation to seek local partnership in order to obtain the necessary 'skills' and 'networks' to navigate local environment, whereas foreign 
investors from more corrupt countries may have possessed such skills and therefore are 'competent' enough to operate alone. This argument makes intuitive sense, but it not without flaws.

One of the problems of the argument is that it assumes that foreign investors are institutional 'takers'. They readily adjust to the host environment to achieve corporate success. But there is evidence in the literature suggesting that MNEs can be powerful bargainers, and have long-term influence on the host institutional environment by insisting their 'own' way of doing business (Chuck and Tadesse, 2006; Ahlquist and Prakash, 2009). If this rationale prevails, then we may find that foreign investors from transparent countries will resist the host inferior institutional environment by going alone in their business to ensure business is conducted in their own and 'correct' way. Indeed, many MNEs have their global corporate image to protect. The potential cost of their involving in 'inappropriate' business practice overseas may dampen their corporate image beyond the simple measure of short-term profitability. Some research also provides empirical evidence suggesting that firm's managerial attitudes and beliefs, and consequently, decisions-making patterns are shaped by their national cultural and institutional environment (Erramillli, 1996). MNEs from transparent home countries are more frown upon corruption than those from corrupt countries ( $\mathrm{Wu}, 2006)$. MNE managers from less corrupt countries are likely to have values similar to those of their home countries. An increasing number of OECD countries also have adopted laws similar to the US Foreign Corrupt Practice Act (FCPA) also means that the home jurisdiction can penalize overseas management for inappropriate practices abroad. Therefore, there is strong reason to expect that MNEs from a relative clean environment may perceive the inferior institutional environment in the host country as a liability and prefer operating alone. We hypothesise:

H1: MNEs from less corrupt countries prefer WOSs to JVs.

H2: The greater the corruption distance that exists between host and home country the higher probability the choice for WOS over JV. 
However, these arguments do not apply for firms from home countries that are equally and more corrupt. These firms are not concerned about the potential of partners behaving corruptly in a corrupt culture. Consequently, the level of corruption in a host market is not part of their mode of entry thought process. Therefore, if a home country of the MNE is equally or more corrupt compared to the host country, corruption will not make difference in the MNE's entry mode decision process. Hence, we hypothesize:

H3: MNEs from MNEs from equally and more corrupt home countries will not prefer WOS to JV.

H4: For MNEs from MNEs from equally and more corrupt home countries, corruption distance will not impact the choice of WOS versus JV.

Treating FDI as a homogenous lump is probably one of the sources of the inconsistent empirical results in the literature. It is becoming clear that local market-seeking and export-oriented FDI respond to corruption in the host environment differently (Hakkala, et al., 2005). It seems correspondingly likely that the two types of FDI also differ in their entry mode strategies. Current literature has suggested that horizontal FDI, compared to vertical one, needs more local input, such as knowledge of local markets, consumer preferences, business practices, and access to local distribution networks, because the primary driver of horizontal FDI is to access local market. As a result, joining forces with local firms could be an attractive option because it will help MNEs obtain needed information and knowledge speedily compared to develop it in house. In addition, horizontal FDI often create direct competition for local firms, therefore, both host government and local firms may view collaboration with MNEs an effective way to reduce direct competition and increase potential knowledge transfer. As a result, there may be more local effort in seeking and initiating partnership with subsidiaries of foreign MNEs.

This motive would be lower for vertical FDI because vertical FDI generates less risk of damaging local competitors. In addition, high control mode may be favored by MNEs 
because of the need to closely coordinate their operation with the rest of the value added chain located in different locations around the globe. Therefore, we hypothesize:

H5: Market orientation influences the entry mode choice in a way that higher local market orientation induces higher likelihood for MNEs to favor JV in relative to WOS. This is true for both MNEs from less corrupt countries and MNEs from equally and more corrupt countries.

Apart from the possible tendency that the level of local market orientation may shift MNE's preference towards $\mathrm{JV}$, we are also interested to explore whether market orientation could also alter MNEs' response to corruption distance. This has never been tested in the literature, but the influence of heterogeneity of companies' strategies or other characteristics on their response to host country characteristics is not uncommon. For example, tacit know-how is found to be a significant and positive predictor explaining MNEs' preference of WOS in relative to JV in knowledge intensive industry, but not in capital-intensive industry (Esther, et al., 2007). Firm's capability can significantly affect their perceived risk associated with different entry mode strategies: low capability firms are found to perceive non-equity entry mode as the safest strategy, but in contrast more capability firms view it as the most risky strategy (Forlani et al., 2008). In the case of corruption distance, we speculate that the desire to access local market, obtain necessary local input, such as local information and knowledge, distribution channels, and navigate local bureaucratic and commercial environment can attenuate the preference of WOS for MNEs from less corrupt countries. This seems particularly likely to take place due to the extraordinary potential of the mass Chinese market, compared to other smaller economics. Therefore, we suggest the following hypothesis to test the possible heterogeneity:

H6: Local-market orientation diminishes the effect of corruption distance on WOS preference among MNEs from less corrupt countries.

Having stated our hypotheses, we explain our empirical strategy in section 3 . 


\section{Empirical strategy}

This research uses FDI data from the city of Suzhou, China. Data from a single city admittedly has limitations, but could be advantageous because inter-regional differences in China can bring more uncontrollable complexity to the investigation (Pan, 2002). The city of Suzhou is located approximately 80 kilometres north of Shanghai, which is the commercial centre of Mainland China. Suzhou is the most important city in Changjiang Delta and is one of the top FDI recipient cities in China with its unique geographic location, well educated work force, and substantially established indigenous industries. Our data set is drawn from the government survey on foreign direct investment activities in 2005 (the survey was conducted in 2006). It contains all entry permits granted to foreign investors in the city between 1981 and 2005 . There are 9564 entries by foreign MNEs from 72 countries and regions throughout the world.

In order to test how the entry strategy of FDI responds to corruption, we use a dichotomous dependent variable to indicate the choice between WOS and JV, in which WOS is indicated by the value of 1 , and JV 0 . For the key dependent variable corruption distance, we choose the corruption index from International Country Risk Group (ICRG) for its widespread country and period coverage. The index is composed in a way that high values indicate low corruption level in the country ${ }^{1}$. The scores range from 1 to 6 . We measure corruption distance in two ways. First, we generate a dummy variable to indicate the direction of corruption distance, namely, whether the home country of the MNE is less corrupt than China or otherwise. Countries which are less corrupt than China are indicated by value 1,0 otherwise. This dummy variable can reveal between the two groups of countries whether MNEs from them respond to corruption in China differently. While majority countries in our sample record persistent positive corruption distance from China, namely, they are less corrupt than Chin across years, some countries, such as Brunei, Indonesia, Panama, Paraguay, and Thailand show to be persistently more corrupt than China. Second, we use two continuous variables to indicate corruption distance for

\footnotetext{
${ }^{1}$ We also collected corruption data from World Governance Indicators (WGI) and Transparency International (TI) and found, for available year and country entries, a high correlation with the ICRG data (see Table 2). This is consistent with the findings of other authors (e.g. Hakkala, et al., 2005) that these measures are highly correlated and supports our use of the single ICRG index owing to its superior coverage.
} 
the two groups of countries respectively. Corruption distance 1 is the absolute differential value between the corruption scores of the home country and China for less corrupt countries. Corruption distance 2 is the absolute differential value between the corruption scores of the home country and China for countries which are equally or more corrupt than China. This will enable us to test whether MNEs from the two groups of countries react to corruption distance differently.

To test our fifth hypothesis, market orientation is measured in two ways to best utilize the data. First, we measure it as a dichotomous variable where horizontal FDI (if the ratio of local sales to total sales is 1) is indicated by the value 1, and vertical FDI (if the ratio of local sales to total sales is 0 ) is indicated by 0 . This variable is called market orientation dummy in our tables to be discussed shortly. This measurement matches the theoretical description of horizontal and vertical FDI perfectly, but it generates unnecessary missing values because, in reality, some subsidiaries have both local sales and export. Therefore, we produce a second measurement, where the level of market orientation is measured by the ratio of local sales to total sales, so that it becomes a continuous, rather than a discrete, variable. This way the sample becomes more inclusive. In our empirical testing, these two variables are used alternatively to assess the effect of market orientation on the entry mode choice. Subsequently, we also create an interaction terms of market orientation and corruption distance 1 to assess whether market orientation attenuates the effect of corruption distance on entry mode choice for MNEs from less corrupt countries.

We also include a host of control variables to supplement the model. The country level control variables are as follows. The first is political risk. As scholars argued that one of the specific reasons for JVs are favoured in Eastern Bloc countries in 1995 is probably because they were unstable, risky and in transition (Tekin-Koru, 2006; Smarzynska and Wei, 2002). It implies that political risk that may induce upright expropriation in the host country needs to be managed in a different manner from petty corruption which merely involves paying extra cost to grease business. While some scholars are able to study 'pervasive' corruption and 'arbitrary' corruption respectively to distinguish the different dimensions of corruption (Uhlenbruck et al, 2006), unfortunately, there is no sufficient 
data on China to enable a meaningful assessment ${ }^{2}$. As an alternative, we control political risk, similar as Lee and Oh (2007). The data is drawn from PRS group. It is a composite index with value ranging between 1 and 9. Higher scores indicate more stable political system. In a similar vein, we include rule of law (Asiedu and Esfahani, 2001) and economic freedom in our model to delineate whether they, instead of corruption, have an effect on the entry mode choice. Data of rule of law is from World Governance Indicators by World Bank Institute. It captures perceptions of the extent to which agents have confidence in and abide by the rules of society, and in particular the quality of contract enforcement, property rights, the police, and the courts, as well as the likelihood of crime and violence. The scores range between -2 and 2 , with higher values indicating better law system. Date of economic freedom is from Heritage Foundation and Wall Street Journal. It measures to what extent the freedom of work, produce, consume, and invest is protected and unconstrained by the state. Higher scores indicate freer marketplace and less government intervention.

In addition, we also control cultural distance, but with important difference in our application from what is seen in most recent literature. Most previous studies have adopted Kogut and Singh's composite index (1988) to specify cultural distance, but the empirical results regarding entry mode choice are decidedly mixed (Tihanyi et al, 2005). The use of the composite index is criticized to lack theoretical relevance to specific crossborder outcomes and therefore should be avoided to generate more conflicting results (Shenkar, 2001; McSweeney, 2002; Kirkman, et al, 2006). What is advocated is distance measures based on single cultural dimensions which show explicit theoretical relevance to the investigated outcome. As a result, we refer to Siegel, et al. (2006) who developed and empirically demonstrated that cultural distance regarding egalitarianism has an impact on FDI. To be specific, the egalitarianism/hierarchy dimension deals with the preferred way to elicit cooperative, productive activity in society and in particular with the issue of power. Two countries with large egalitarianism distances may suffer from

\footnotetext{
${ }^{2}$ We attempted to capture the different impact of pervasive and arbitrary corruption, but the data source used by Uhlenbruck et al, 2006, namely World Business Environment Survey, does not contain sufficient data on China.
} 
lower FDI flows because of irreconcilable perceptions of power, equality and tolerance of different business practices (Siegel, et al., 2006).

Furthermore, geographic distance is controlled as an economic factor (Leamer and Levinsohn, 1995; Caves, 1996; di Mauro, 2000). Transaction cost economics suggests that headquarter and subsidiaries can be understood as a type of principal-agent relation (Grossman and Hart, 1986; O’Donnell, 1997). A key difference between WOS and JV is that joint ventures have multiple principles, which makes the goal incongruence problem potentially more severe in JVs than in WOSs. Compared to a JV, a WOS has superior ability to install various monitoring instruments, such as replicating the organizational rules and procedures into the subsidiaries, demanding free and transparent information flows from and to the subsidiaries, and assigning expatriates. However, Grossman and Helpman (2004) suggested that, ceteris paribus, it becomes increasingly difficult over longer geographic distances to have timely communication and accurate information flows between headquarter and subsidiaries; therefore the monitoring efficiency deteriorates with longer geographic distance. As a result, MNEs may be less averse to setting up joint ventures when the advantages of full ownership arrangements are weakened by geographic distance.

We also consider industry specific factors. Based on the empirical evidence of GomesCasseres (1990), Makino and Neupert (2000), Chen and Hennart (2002) among others, we use an industry dummy to identify resource-intensive industries. The common view is that resource-based industries tend to have high local equity participation because access to natural resources is often controlled by local incumbents. In our investigation the following is coded as resource-intensity industry: agriculture, forestry, farming, agricultural processing, food, beverages, textiles, wood, paper, tyre, non-metal mineral manufacturing, black metal processing and metal processing, indigenous craft products and recycling. Policy related factor is also taken into account. FDI into China was subject to tight control (Teng, 2004) during the 1980s and early 1990s. In approving projected FDI, the Chinese government tended to favour joint ventures, especially in restricted industries such as auto manufacturing. However, the situation has been quietly changing. 
With the implementation of the Provisional Guidelines on Foreign Investment Projects issued in 1995, the Chinese government has loosened its restrictions on full ownership arrangements. Therefore, we predict that MNEs are more likely to establish a WOS than a JV after the implementation of the Provisional Guidelines on Foreign Investment Projects in 1995. Our data set makes it possible to control for the following subsidiary characteristics. Project size is measured by the natural log of total assets of the subsidiary. The natural $\log$ of the total foreign capital invested in the project can reflect the involvement and commitment of the foreign MNEs in the subsidiary. Capital intensity, measured as total assets per employee, can indicate the asset tangibility of the operation. Labour productivity, measured as net profit per employee, may show the efficiency of the operation. Table 3 summarizes the variables, their measurement, and data sources. Table 4 presents the descriptive statistics, and Table 5 reports the correlation matrix of the main variables.

\section{Results}

We report our results in a step-wise manner to build up our discussion. Firstly, Table 6 reports a preliminary analysis of our first five hypotheses in a simplistic manner to establish the basic findings. We then focus on the sub-sample where the results for less corrupt countries (than China) are presented in Table 6. This is to focus our discussion on to what extent our sixth hypothesis obtains supporting evidence in our investigation.

In Table 6, we employ random effects logistic regressions to control for the possible correlation between subsidiaries from a common home country. This enables the models to accommodate this country level cluster effect. To minimize the loss of observations, we did not include economic freedom as a country level control variable because its inclusion causes collinearity with other country level variables, and also reduces the sample size drastically. Model 1 serves as the baseline, where we have 5985 observations across 52 countries with complete information. The Wald chi square of the model is 1018.292 and the log likelihood of the model is -2399.497. In this model, corruption distance dummy shows to have a marginally significant and positive impact on entry 
mode choice, which suggests that MNEs from less corrupt countries prefer to have WOS in relative to $\mathrm{JV}$ compared to their peers from equally or more corrupt countries than China. All country level control variables do not show statistical significance; in contrast, all project level control variables have achieved statistical significance with expected signs, except labor productivity which shows to have no correlation with entry mode choice. In specific, resource intensity industry, the size of the project, and capital intensity of the project increase the likelihood of JV being chosen over WOS, whereas projects with large foreign capital injection are more likely to be WOS. Variable year_1995 was dropped out of the model because of collinearity. This is primarily because the available data of country level variables mostly are from years after 1995 . When we did not include any country level variables, year_1995 has always achieved statistically significant and positive result, suggesting an overall important influence on MNEs' preference of WOS after the government loosened up the ownership restriction in 1995. We do not report these results for the sake of brevity. To sum up, Model 1 seems to establish the evidence that overall MNEs from less corrupt countries prefer WOS compared to their peers from equally or more corrupt home countries than China. This lends support to our first hypothesis. This also supports our argument in the third hypothesis that MNEs from MNEs from equally and more corrupt home countries do not prefer WOS to JV. The main effect of corruption distance dummy is also visualized in Graph 1. Although we achieve a statistically significant result, the coefficient of this dummy is rather weak, standing at 0.042 , which explains the very gradual slope shown in Graph 1.

Model 2 continue to assess whether higher corruption distance induces MNEs from less corrupt countries to favor WOS to JV. It is noted that Corruption distance 1 is a continuous variable. It achieves a statistically significant and positive result, suggesting that the more transparent the home country of the MNE is, the more likely it is to choose WOS over JV. This effect is also visualized in Graph 2, where we can see that the slope shows to be less flat than in Graph 1 , which reflects on the higher coefficient $(0.115)$ that corruption distance 1 obtains in this specification. 
In direct contrast, corruption distance 2 in Model 3 obtained a statistically insignificant result, which indicates that corruption distance between China and those equally or even more corrupt countries does not have significant influence on the entry mode decisions of their MNEs. We also visualize this effect in Graph 3 despite the insignificant result. We can see that the slope is slightly steeper (coefficient 0.261) than that in Graph 2 (coefficient 0.115 ), but it is statistically insignificant. The results confirm our speculation that, for less corrupt home countries, the larger the corruption distance between them and China, the more likely their MNEs would favor WOS in relative to JV; but corruption distance is not an important predictor of entry mode choice for MNEs from those equally or more corrupt countries than China. It is noted that in Model 3, country level variables were dropped because they cause collinearity. This is due to the combination of smaller sample size and the fact that most country level variables are highly correlated with each other within this stripped sample. All the project level control variables in Model 3 attain similar results as that in Model 1 and Model 2.

Model 4 and Model 5 provide a preliminary glimpse on the effect of market orientation, which is measured as a dummy variable in the former, and a continuous one in the latter. Both models provide strong support for the argument that the level of local market orientation (horizontal FDI), compared to export orientation (vertical FDI), is a significant predictor of entry mode choice. Local market orientation significantly reduces the probability that WOS will be chosen over JV, suggesting a powerful effect that the need to access market and its knowledge can curve the tendency of choosing high control mode for its operation. More interestingly, in Model 4, rule of law obtains a negative and marginally significant result, suggesting the better rule of law system the home country of the MNE has, the more likely it is to choose JV over WOS. This might reflect a tendency for MNEs from countries with better rule of law system to seek local partnership to deal with potential disputes and conflicts due to substandard quality of contract enforcement, property rights protection, and the function of court in China. This result stands in Model 5 as well. Apart from this interesting new finding in Model 4 and Model 5, the rest results are qualitatively similar to those of Model 1 and Model 2. 
Table 7 reports the result for MNEs from less corrupt countries with a focus on the interaction term of corruption distance 1 and market orientation. In Model 1, corruption distance 1 attains a positive and significant result, consistent with those in Table 6. This suggests that larger corruption distance between home countries of MNEs and China induces MNEs to favor WOS over JV as their entry mode choice. Market orientation dummy receives a negative and significant result, again, consistent with what we found in Table 6. This establishes the evidence that horizontal FDI, compared to vertical FDI, prefers JV as their entry mode choice. The rest of control variables, including both country level and project level ones, receive similar results as those in Table 6. It is noted that the sample size becomes much smaller because of only small number of countries have complete data for the three country level factors: political risk, rule of law and economic freedom. Overall, the model has a good explanatory power judging by the Wald chi square and log likelihood. It is also noted that rule of law receives a significant and negative result in Model 1, consistent with what we found in Table 6.

In Model 2, we include the interaction term of corruption distance 1 and market orientation dummy. We found that the interaction term carries a negative but insignificant sign. But corruption distance 1 is still a significant predictor in this model. Therefore, we interpret that when corruption distance is considered together with market orientation, its significant influence on the preference of a WOS over JV declines. To put it another way, local market orientation reduces the tendencies for MNEs from less corrupt countries to favor WOS. This suggests support for our sixth hypothesis. To re-assess this result, we use market orientation, a continuous variable, as an alternative variable to replace its dummy in Model 3 and Model 4, which are more inclusive than Model 1 and Model 2. The results obtained are qualitatively identical. The effect of this key interaction term is visualized in Graph 4, where we see the $\mathrm{x}$-axis represents this interaction term measured by Corruption distance 1 multiply market orientation dummy. It is noted although the slope is steep, statistically it is not significant. But what is clear from our analysis, especially from the contrast between graph 2 and Graph 4, is that local market orientation substantially attenuates the tendency for MNEs to prefer WOS. 
We now sum up our results. First of all, we found substantial evidence suggesting the direction of corruption distance matters. MNEs from less corrupt countries, compared to their peers from equally or more corrupt countries, prefer WOS over JV as their entry strategy. The larger the corruption distance between their home countries and China, the more likely they favor WOS over JV. Local market oriented operations are more likely to be JVs regardless whether the MNE is from more or less corrupt country. For those from less corrupt countries, their tendency to prefer WOS is attenuated with the increased level of local market orientation.

There are some limits we like to reflect that may caution us with our results. First, it is apparent that the samples used contain much smaller number of observations than the full sample promised to. Two factors have contributed to this. One is that country level data are not available for some places, such as Barbados, Bermuda, British Virgin Island, Samoa, St Kitts-Nevis, Lesotho, Liechtenstein, some East European countries, and more importantly Taiwan ${ }^{3}$. In total, they account for approximately $35 \%$ of the total sample. Second, institutional variables, such as political risk, rule of law and economic freedom are mostly available after year 1995, which caused more data loss in the investigation. For the two groups of countries, one is less corrupt and the other no less corrupt than China, the latter usually has a very small sample sizes due to the fact that only a selected number of countries are more corrupt than China. If future studies can contain a more balanced data to explore the issue of corruption distance, it may enable a more robust assessment regarding how MNEs from more corrupt countries behave. We also develop a negative hypothesis (hypothesis 3), which can be controversial. But since our main result regarding hypothesis 1 is strongly supported, the essence of our argument regarding hypothesis is therefore corroborated. Another limit of the research is that we do not have MNE parent data, which has limited our statistical test to only subsidiary and country level factors. Thirdly, our results regarding the attenuating impact of local market orientation on MNEs' response to corruption distance could be China specific. It is important if future studies could replicate this test in other countries' context.

\footnotetext{
${ }^{3}$ Regional level data of Taiwan are seriously incomplete because many macro databases simply do not include Taiwan as an independent economy. However, Taiwan has contributed to over 17\% of total FDI received by Suzhou.
} 


\section{Discussions and Conclusions}

Corruption has been a common concern for international investors. For MNEs which bear considerable commitment to their overseas expansion, how to react to corruption in the host environment is of interest to both practitioners and policy markers. Our study provides new evidence which lends some support to Tekin-Koru (2006), where corruption distance is also found to lead to a preference of WOS for MNEs operating in Turkey. This is perhaps because China, similar to Turkey, has a relative stable political environment and has hosted FDI for a few decades with remarkably successful experience despite its high corruption level. However, caution has to be taken since Tekin-Koru (2006) did not take the direction of corruption distance into account. Our investigation also controls for project level variables that have shown to have significant power in predicting the entry mode choice of MNEs, which were not considered in Tekin-Koru (2006). Another interesting finding in our analysis is that the home country's rule of law system influences its MNEs decision making regarding entry mode choice. MNEs from countries with stronger rule of law favor collaborating with local firms perhaps to avoid potential difficulties that may arise due to substandard quality of contract enforcement, property rights protection, and the function of court in China.

As the Chinese government has been constantly encouraging the formation of joint ventures between foreign firms and indigenous Chinese firms in the hope that it will accelerate potential knowledge spillovers from FDI, our study suggests that reducing the prevailing corruption will help the government to attain its purpose. Although the huge consumer base has helped China in inducing MNEs to establish joint ventures so far, an improvement in the country-wide institutional environment would no doubt provide more confidence for MNEs considering whether to set up more joint ventures in China. From MNEs' perspective, especially those from transparent countries, a wholly owned subsidiary gives them higher control over the way their business and operations are organized and conducted. The extra cost that may occur to deal with corrupt environment 
could be justified considering the significant implications of protecting and sustaining their corporate governance and global image. Conflict with local partners regarding how to deal with corrupt officials could be equally or more taxing than resisting them in their own way. The bargaining power of MNEs, especially those large ones from developed nations, makes it all the more likely that they will encounter less corruption in the process of entry because they are usually the targets of many local governments compete to attract and appeal to. Therefore, our investigation suggests that corruption in China does not justify partnering with local firms. MNEs can go along in their operation to deal with the problem. Future research can seek to establish whether there is a causal relation between the choice of entry mode and the performance of MNEs in China. A formal assessment of that type would provide MNEs with a more precise guide on how to design their entry strategies. In addition, future studies can examine whether there is a learning effect with respect to MNE's entry strategies. Do MNEs respond to corruption differently in their repeated investment in China? Do they learn from their peers in the same industry, or from same home country, regarding which entry mode to choose to best deal with corruption? A systematic examination of these questions will undoubtedly provide a more dynamic understanding of how corruption in China influences MNEs'strategies. 


\begin{tabular}{|c|c|c|c|c|c|c|c|}
\hline Author & Sample data & Research focus & $\begin{array}{l}\text { Measure } \\
\text { ment of } Y\end{array}$ & $\begin{array}{l}\text { Measurement } \\
\text { of corruption }\end{array}$ & Other variables & Methodology & Results \\
\hline \multirow[t]{2}{*}{$\begin{array}{l}\text { Smarzynska } \\
\text { and Wei } \\
\text { (2002) }\end{array}$} & \multirow[t]{2}{*}{$\begin{array}{l}720 \text { projects originating } \\
\text { from } 25 \text { countries in } 22 \\
\text { CEE countries }\end{array}$} & \multirow[t]{2}{*}{$\begin{array}{l}\text { 1) Invest or not } \\
\text { invest } \\
\text { 2) WOS or JV }\end{array}$} & \multirow{2}{*}{$\begin{array}{l}\text { 1) } 1 / 0 \\
\text { (dummy) } \\
\text { 2). } 1 / 0 \\
\text { (dummy) }\end{array}$} & \multirow[t]{2}{*}{$\begin{array}{l}\text { WDR, } \\
\text { Neumann, \& } \\
\text { KKZ }\end{array}$} & $\begin{array}{l}\text { Country: GDP, GDP per } \\
\text { capita, corporate tax, } \\
\text { distance }\end{array}$ & \multirow[t]{2}{*}{$\begin{array}{l}\text { Single-equation probit regression } \\
\text { with between } 2808 \text { to } 3570 \\
\text { observations }\end{array}$} & \multirow[t]{2}{*}{$\begin{array}{l}\text { High corruption leads to } \\
\text { preference of JV }\end{array}$} \\
\hline & & & & & $\begin{array}{l}\text { Parent: size, diversity, } \\
\text { technology intensity or } \\
\text { advertising intensity }\end{array}$ & & \\
\hline $\begin{array}{l}\text { Tekin-Kory } \\
\text { (2006) }\end{array}$ & $\begin{array}{l}\text { Foreign invested firms } \\
\text { from } 88 \text { country or origin } \\
\text { in Turkey }\end{array}$ & $\begin{array}{l}\text { Counts of WOS } \\
\text { and JV }\end{array}$ & $\begin{array}{l}\text { Discrete } \\
\text { number } \\
\text { of WOS } \\
\text { and JV }\end{array}$ & $\begin{array}{l}\text { Transparency } \\
\text { international: } \\
\text { Corruption } \\
\text { index }\end{array}$ & $\begin{array}{l}\text { Country: GDP, skill } \\
\text { difference, distance, border, } \\
\text { experience }\end{array}$ & $\begin{array}{l}\text { Two equations using random } \\
\text { negative binomial model to } \\
\text { estimate the number of WOS and } \\
\mathrm{JV} \text {, with } 968 \text { observations }\end{array}$ & $\begin{array}{l}\text { High corruption distance leads } \\
\text { to preference of WOS }\end{array}$ \\
\hline \multirow[t]{2}{*}{$\begin{array}{l}\text { Uhlenbruck } \\
\text { et al (2006) }\end{array}$} & \multirow[t]{2}{*}{$\begin{array}{l}220 \text { telecommunication } \\
\text { projects in } 64 \text { emerging } \\
\text { countries }\end{array}$} & \multirow[t]{2}{*}{$\begin{array}{l}\text { Preference } \\
\text { among WOS, JV } \\
\text { and non-equity } \\
\text { mode }\end{array}$} & \multirow[t]{2}{*}{$\begin{array}{l}\text { Category } \\
\text { variable }\end{array}$} & \multirow{2}{*}{$\begin{array}{l}\text { Transparency } \\
\text { international: } \\
\text { Corruption } \\
\text { index, World } \\
\text { Business } \\
\text { Environment } \\
\text { Survey }\end{array}$} & $\begin{array}{l}\text { Country: GDP, GDP per } \\
\text { capita, Regulatory policy, } \\
\text { political risk, FDI restrictions, } \\
\text { WTO commitments }\end{array}$ & \multirow[t]{2}{*}{$\begin{array}{l}\text { Multinomial logistic regression } \\
\text { with } 220 \text { observations }\end{array}$} & \multirow[t]{2}{*}{$\begin{array}{l}\text { Pervasive corruption leads to } \\
\text { preference of WOS; } \\
\text { Arbitrary leads to preference of } \\
\text { JV. }\end{array}$} \\
\hline & & & & & $\begin{array}{l}\text { Subsidiary: size, technology } \\
\text { intensity, state participation }\end{array}$ & & \\
\hline \multirow[t]{3}{*}{$\begin{array}{l}\text { Asiedu and } \\
\text { Esfahani } \\
\text { (2001) }\end{array}$} & \multirow[t]{3}{*}{$\begin{array}{l}21300 \text { non-bank affiliates } \\
\text { of U.S. MNEs in } 42 \\
\text { countries }\end{array}$} & \multirow[t]{3}{*}{$\begin{array}{l}\text { 1). WOS or JV } \\
\text { 2). Equity share } \\
\text { (continuous) }\end{array}$} & \multirow[t]{3}{*}{$\begin{array}{l}\text { 1) } 1 / 0 \\
\text { (dummy) } \\
\text { 2) } \\
\text { percent of } \\
\text { equity }\end{array}$} & \multirow[t]{3}{*}{$\begin{array}{l}\text { ICRG: Rule of } \\
\text { law } \\
\text { \& corruption } \\
\text { index }\end{array}$} & $\begin{array}{l}\text { Country: infrastructure } \\
\text { availability, local knowledge, } \\
\text { education, social-cultural } \\
\text { distance, openness, domestic } \\
\text { technology capability, FDI } \\
\text { policy }\end{array}$ & \multirow{3}{*}{$\begin{array}{l}\text { 1. Single-equation probit } \\
\text { regression } \\
\text { with between } 1523 \text { to } 2416 \\
\text { observations } \\
\text { 2. Truncated model on foreign } \\
\text { equity share of joint ventures with } \\
331 \text { observation }\end{array}$} & \multirow[t]{3}{*}{$\begin{array}{l}\text { Better rule of law leads to } \\
\text { preference of JV; } \\
\text { The impact of corruption on the } \\
\text { choice between WOS and JV is } \\
\text { insignificant. }\end{array}$} \\
\hline & & & & & $\begin{array}{l}\text { Industry: technology } \\
\text { intensity, resource intensity, } \\
\text { vertical integration, } \\
\text { marketing seeking }\end{array}$ & & \\
\hline & & & & & $\begin{array}{l}\text { Parent: Non-contractible } \\
\text { assets, parent size, diversity, } \\
\text { international experience }\end{array}$ & & \\
\hline
\end{tabular}




\begin{tabular}{l|l|c|c|}
\hline \multicolumn{4}{|l|}{ Table 2: Correlation matrix between ICRG, TI, and WGI corruption data in our sample } \\
\hline & ICRG & TI & WGI \\
\hline ICRG & 1.000 & & \\
\hline TI & $0.959^{* *}$ & 1.000 & 1.000 \\
\hline WGI & $0.955^{* *}$ & $0.989^{* *}$ & \\
\hline${ }^{*}\left({ }^{* *}\right)$ indicates correlation is significant at the $0.05(0.01)$ & level (two-tailed, Pearson). \\
ICRG is International Country Risk Group \\
TI is Transparency International \\
WGI is World Governance Indicators from World Bank
\end{tabular}




\begin{tabular}{|c|c|c|}
\hline Variable & Measurement & Data source \\
\hline \multicolumn{3}{|l|}{ Dependent variable } \\
\hline Entry mode choice & WOS $=1 ; J V=0$ & This study \\
\hline \multicolumn{3}{|l|}{ Independent variables } \\
\hline Corruption distance (dummy) & Less corrupt countries $=1 ;$ otherwise $=0$ & PRS group and this study \\
\hline Corruption distance 1 & $\begin{array}{l}\text { Absolute value of the corruption score differential between the home country and China } \\
\text { for home countries which are less corrupt than China }\end{array}$ & PRS group and this study \\
\hline Corruption distance 2 & $\begin{array}{l}\text { Absolute value of the corruption score differential between the home country and China } \\
\text { for home countries which are equally or more corrupt than China }\end{array}$ & PRS group and this study \\
\hline Market orientation (dummy) & Horizontal FDI=1; Vertical FDI=0 & This study \\
\hline Market orientation & Local sales/Total sales & This study \\
\hline Corruption distance $1 *$ Market orientation (dummy) & See above & This study \\
\hline Corruption distance $1 *$ Market orientation & See above & This study \\
\hline Corruption distance $2 *$ Market orientation (dummy) & See above & This study \\
\hline Corruption distance $2 *$ Market orientation & See above & This study \\
\hline \multicolumn{3}{|l|}{ Control variables } \\
\hline Political risk & A composite index of 5 elements. Score 1-9. Higher values indicate more stable system. & PRS group \\
\hline Rule of law & Score -2 to 2 . Higher values indicate better law system & World Bank Institute. \\
\hline Economic feedom & A composite index of 10 components & Heritage Foundation \& WS \\
\hline Egalitarian distance & Egalitarian score of the foreign country - egalitarian score of China & Siegel et al 2006 \\
\hline Geographic distance & $\begin{array}{l}\text { Natural log of physical distance in miles between Suzhou and the capital city of investing } \\
\text { country }\end{array}$ & This study \\
\hline Resource industry & Resource intensity industry $=1$; otherwise $=0$ & Chen and Hennart 1992 \\
\hline Year_1995 & After $1995=1 ;$ otherwise $=0$ & This study \\
\hline Size & The natural log of total fixed assets $(10,000 \mathrm{RMB})$ reported by the registered project & This study \\
\hline Total foreign capital investment & The natural log of foreign investment $(10,000 \mathrm{RMB})$ received by the registered project & This study \\
\hline Capital intensity & The ratio of total fixed assets divided by the number of employee & This study \\
\hline Labor productivity & Net profit divided by the number of employee & This study \\
\hline
\end{tabular}




\begin{tabular}{|l|l|l|l|l|}
\hline Table 4: Descriptive statistics for the main variables \\
\hline & Mean & Std. Dev. & Min & Max \\
\hline Entry mode choice & 0.78 & 0.41 & 0.00 & 1.00 \\
\hline Corruption distance (dummy) & 0.88 & 0.31 & 0.00 & 1.00 \\
\hline Corruption distance 1 & 1.92 & 0.84 & 0.50 & 5.00 \\
\hline Corruption distance 2 & 0.16 & 0.40 & 0.00 & 3.00 \\
\hline Market orientation dummy & 0.82 & 0.37 & 0.00 & 1.00 \\
\hline Market orientation & 0.60 & 0.42 & 0.00 & 1.00 \\
\hline Political risk & 7.73 & 0.46 & 4.38 & 9.06 \\
\hline Rule of law & 1.18 & 0.38 & -1.81 & 1.99 \\
\hline Economic freedom & 78.14 & 9.78 & 44.34 & 90.00 \\
\hline Egalitarian distance & 0.29 & 0.21 & -0.06 & 1.07 \\
\hline Geographic distance & 7.52 & 1.10 & 6.21 & 9.39 \\
\hline Resource industry & 0.28 & 0.45 & 0.00 & 1.00 \\
\hline Year_1995 & 0.90 & 0.29 & 0.00 & 1.00 \\
\hline Size & 16.33 & 2.24 & 0.00 & 22.92 \\
\hline Total foreign capital investment & 4.70 & 1.71 & 0.51 & 10.91 \\
\hline Capital intensity & 0.02 & 0.10 & 0.01 & 10.00 \\
\hline Labor productivity & 0.05 & 3.98 & 0.02 & 341.66 \\
\hline
\end{tabular}




\begin{tabular}{|c|c|c|c|c|c|c|c|c|c|c|c|c|}
\hline Entry mode choice & 1 & & & & & & & & & & & \\
\hline Corruption distance (dummy) & .786 & 1 & & & & & & & & & & \\
\hline Market orientation & -0.2111 & 0.365 & 1 & & & & & & & & & \\
\hline Political risk & 0.1084 & 0.448 & -0.2272 & 1 & & & & & & & & \\
\hline Rule of law & -0.0334 & 0.492 & -0.0438 & 0.4446 & 1 & & & & & & & \\
\hline Economic freedom & -0.1591 & 0.312 & 0.2483 & -0.5355 & 0.2519 & 1 & & & & & & \\
\hline Egalitarian distance & -0.012 & 0.210 & -0.0094 & -0.0545 & 0.5536 & 0.142 & 1 & & & & & \\
\hline Geographic distance & 0.0711 & 0.103 & -0.1605 & 0.2259 & 0.3829 & -0.3948 & 0.7072 & 1 & & & & \\
\hline Resource industry & -0.1089 & 0.039 & 0.1807 & -0.0818 & -0.0132 & 0.107 & -0.0209 & -0.0558 & 1 & & & \\
\hline Size & -0.1145 & -0.029 & -0.0517 & -0.0733 & -0.091 & 0.0809 & -0.0654 & -0.0854 & -0.0098 & 1 & & \\
\hline Total foreign capital investment & 0.2423 & 0.081 & -0.0934 & -0.0035 & 0.0044 & 0.0628 & -0.0042 & -0.0487 & -0.0639 & 0.5894 & 1 & \\
\hline Capital intensity & 0.0117 & 0.034 & 0.046 & -0.0204 & 0.0458 & 0.0447 & 0.0515 & 0.0186 & -0.0614 & -0.4587 & -0.023 & 1 \\
\hline Labor productivity & -0.0456 & 0.067 & -0.0743 & 0.0479 & -0.0156 & -0.0703 & -0.0319 & 0.015 & 0.0074 & 0.1516 & 0.0033 & -0.3652 \\
\hline
\end{tabular}




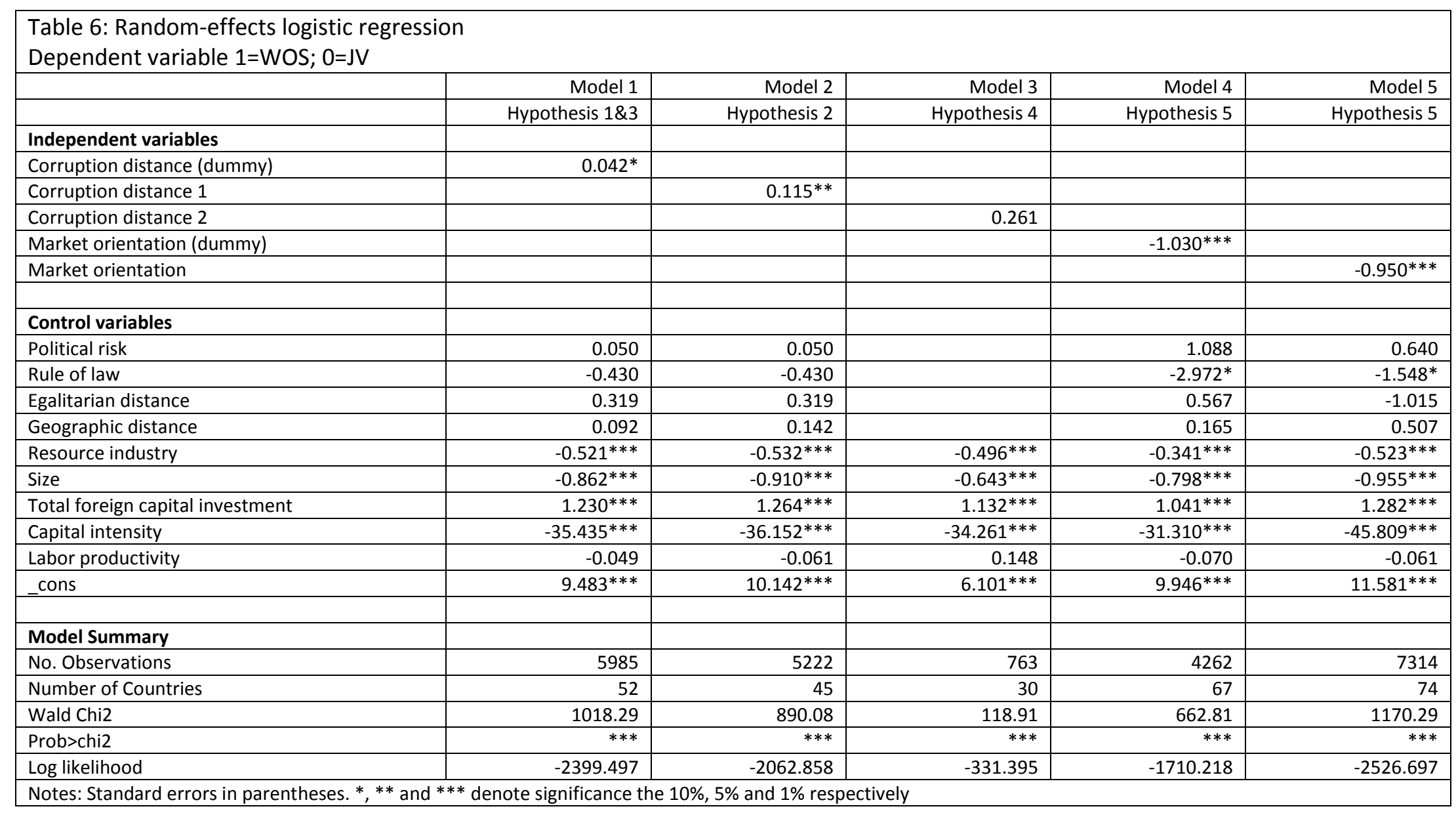




\begin{tabular}{|c|c|c|c|c|}
\hline & Model 1 & Model 2 & Model 3 & Model 4 \\
\hline & & Hypothesis 6 & & Hypothesis 6 \\
\hline \multicolumn{5}{|l|}{ Independent variables } \\
\hline Corruption distance 1 & $0.143^{*}$ & $0.103^{*}$ & $0.127^{*}$ & $0.114^{*}$ \\
\hline Market orientation dummy & $-1.030 * * *$ & -0.159 & & \\
\hline Corruption distance $1 *$ Market orientation dummy & & -0.591 & & \\
\hline Market orientation & & & $-0.942 * * *$ & -0.172 \\
\hline Corruption distance $1 *$ Market orientation & & & & -0.383 \\
\hline \multicolumn{5}{|l|}{ Control variables } \\
\hline Political risk & 1.031 & 0.891 & 0.330 & 0.250 \\
\hline Rule of law & $-2.905^{*}$ & $-2.631^{*}$ & $-1.222^{*}$ & $-1.063^{*}$ \\
\hline Economic freedom & 0.015 & 0.009 & 0.008 & 0.004 \\
\hline Egalitarian distance & 1.108 & 0.955 & -1.213 & -1.246 \\
\hline Geographic distance & 0.151 & $0.120 *$ & $0.423^{*}$ & 0.399* \\
\hline Resource industry & $-0.340 * * *$ & $-0.336 * * *$ & $-0.479 * * *$ & $-0.477^{* *}$ \\
\hline Size & $-0.882 * * *$ & $-0.880 * * *$ & $-1.107^{* * *}$ & $-1.107^{* * *}$ \\
\hline Total foreign capital investment & $0.991^{* * *}$ & $0.987^{* * *}$ & $1.356 * * *$ & $1.356 * * *$ \\
\hline Capital intensity & $-33.811^{* * *}$ & $-32.134 * * *$ & $-32.043 * * *$ & $-32.069 * * *$ \\
\hline Labor productivity & -0.211 & 0.200 & 0.220 & -0.213 \\
\hline _cons & 4.935 & 5.351 & 9.413 & 9.732 \\
\hline \multicolumn{5}{|l|}{ Model Summary } \\
\hline No. Observations & 766 & 766 & 1211 & 1211 \\
\hline Number of Countries & 9 & 9 & 9 & 9 \\
\hline Wald Chi2 & 151.33 & 151.48 & 253.92 & 253.81 \\
\hline Prob>chi2 & $* * *$ & $* * *$ & $* * *$ & $* * *$ \\
\hline Log likelihood & -376.544 & -366.599 & -498.850 & -498.463 \\
\hline
\end{tabular}




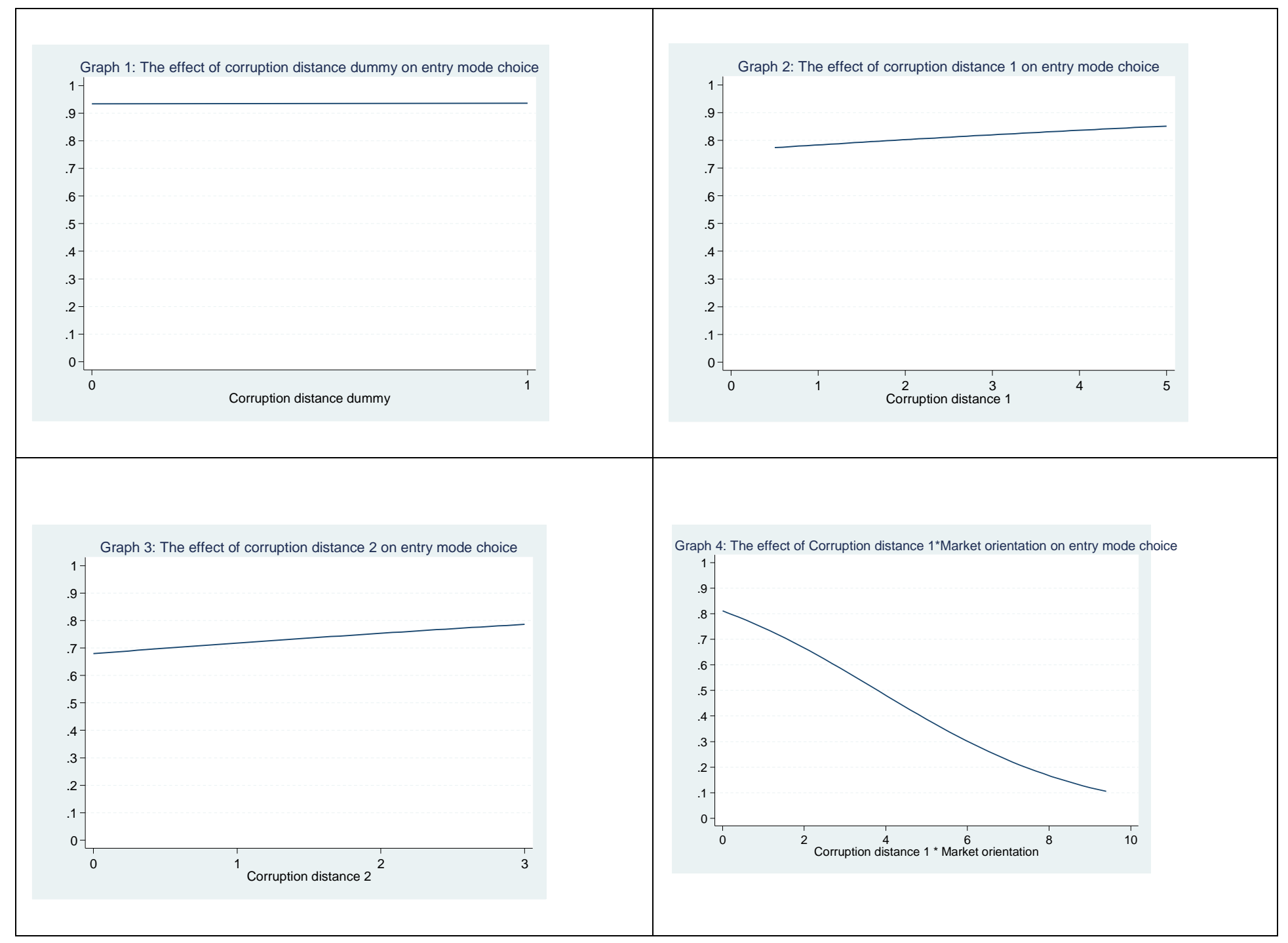




\section{References}

Abed, G. and Gupta, S. 2002. Governance, Corruption and Economic Performance. International Monetary Fund, Washington DC.

Ahlquist, J. and Prakash, A. 2009 FDI and the cost of contract enforcement in developing countries. Policy Sciences.

Aizenman, J. \& Spiegel, M., 2006. Institutional Efficiency, Monitoring Costs and the Investment Share of FDI. Review of International Economics, 14, 4, 683-697.

Anderson, E. and Gatignon, H., 1986. Modes of Foreign Entry: A Transaction Cost Analysis and Propositions. Journal of International Business Studies. 17, 1-26.

Anderson, C. and Tverdova, Y., 2003. Corruption, political allegiance, and attitudes toward government in contemporary democracies. American Journal of Political Science. 47, 91-109.

Asiedu, E. and Esfahani, H., 2001. Ownership structure in Foreign Direct Investment Projects. The Review of Economics and Statistics. 83, 4, 647-662

Boycko, M. Shleifer, A. and Vishny, R., 1995. Privatizing Russia. Cambridge, Mass: MIT Press.

Caves, R.E., 1996. Multinational Enterprises and Economic Analysis. Cambridge University Press. Cambridge.

Chen, S., and Hennart J., 2002. Japanese Investors' Choice of Joint Ventures versus Wholly Owned Subsidiaries: The Role of Market Barriers and Firm Capabilities, Journal of International Business Studies, 33, 1, 1-18.

Cheung, S., 1996. A Simplistic General Equilibrium Theory of Corruption. Contemporary Economic Policy. XIV, 1-5.

Chuck, K. and Tadesse, S. 2006 The MNC as an agent of change for host-country institutions: FDI and corruption. Journal of International Business Studies. 37, 767-785.

Duanmu, J. (Forthcoming). Firm heterogeneity and location choice of Chinese Multinational Enterprises (MNEs). Journal of World Business.

Dunning, J., 1995. Reappraising the Eclectic Paradigm in an Age of Alliance Capitalism. Journal of International Business Studies. 26, 3, 462-491.

Egger, P. and Winner, H., 2006. How Corruption Influences Foreign Direct Investment: A Panel Data Study. Economic Development and Cultural Change. 54, 2, 459-486. 
Erramilli, K. M. 1996. Nationality and subsidiary ownership patterns in multinational corporations. Journal of International Business Studies. 26,225-248.

Esther, S. Jose, P. and Louis, H. 2007 Strategic Variables That Influence Entry Mode Choice in Service Firms. Journal of International Marketing. 15(1): 67-91.

Forlano, D. Parthasarathy, M. And Keaveney, S. (2008) Managerial risk perceptions of international entry-mode strategies. International Marketing Review; 2008, Vol. 25 Issue 3, p292-311.

Gomes-Casseres, B., 1990. Firm Ownership Preferences and Host Government Restrictions: An Integrated Approach. Journal of International Business Studies, 21/1,122.

Grossman, S. J. and Hart, O., 1986. The cost and benefits of ownership: a theory of vertical and lateral integration." Journal of Political Economy, 94, 4, 691-719.

Grossman, G. and Helpman, E., 2004. Managerial incentives and the international organization of production. Journal of International Economics, 63, 237-262.

Hakkala, K. Norback, P. and Svaleryd, H., 2005. Asymmetric Effects of Corruption on FDI: Evidence from Swedish Multinational Firms. The Research Institute of Industrial Economics. Working paper. 641.

Habib, M. and Zurawicki, L., 2002. Corruption and Foreign Direct Investment. Journal of International Business Studies. 33, 2, 291-307.

Johnson, J. and Paul, F., 1975. The Internalization of the Firm: Four Swedish Cases. Journal of Management Studies. 12, 30, 305-322.

Kaufmann, D. and Wei, S., 1999. Does Grease Money Speed Up the Wheels of Commerce? The World Bank and Harvard University.

Kirkman, B. Lowe, K. and Gibson, C., 2006. A Quarter Century of Culture's Consequences: A Review of Empirical Research Incorporating Hofstede's Culture Value Framework. Journal of International Business Studies. 37, 3, 285-320.

Kogut, B. and Singh, H., 1988. The effect of national culture on the choice of entry mode. Journal of International Business Studies. 19, 3, 411-432.

Lambert-Mogiliansky, A., Majumdar, M. and Radner, R., 2007. Strategic analysis of petty corruption: Entrepreneurs and bureaucrats. Journal of Development Economics. 83, 351-367. 
Lee, S. and Oh, K. 2007. Corruption in Asia: Pervasiveness and arbitrariness. Asia Pactific Journal of Management. 24, 97-114.

Leamer, E. and Levinsohn, J., 1995. International Trade Theory: the Evidence. in Grossmon, G. and Rogoff, K. (eds) Handbook of International Economics. Vol. 3 Elsevier Amsterdam.

Markusen, J.R. and Maskus, K.E., 2002. Discriminating among alternative theories of the multinational enterprise,_Review of International Economics, 10, 4, 694-707.

Mauro, P., 1995. Corruption and growth. Quarterly Journal of Economics. 110, 681-712.

di Mauro, F., 2000. The Impact of Economic Integration on FDI and Exports: a Gravity Approach. CEPS Working Paper Series. No. 156.

Makino, S. and Neupert, K.E., 2000. National Culture, Transaction Costs and the Choice between Joint Venture and Wholly Owned Subsidiary. Journal of International Business Studies. 31, 4, 705-713.

McSweeney, B., 2002. Hofstede's model of national cultural differences and their consequences: a triumph of faith - a failure of analysis. Human Relations. 55, 1, 89-118.

Monnte, A. and Papagni, E., 2007. The determinants of corruption in Italy: Regional panel data analysis. European Journal of Political Economy. 23, 379-396.

Morschett, D. Schramm-Klein, H., and Swoboda, B. (2010) Decades of research on market entry modes: What do we really know about external antecedents of entry mode choice? Journal of International Management. 16,1,60-77.

Murphy, K. Shleifer, A. and Vishny, R., 1991. The allocation of talent: implications for growth. Quarterly Journal of Economics. 106, 503-530.

O’ Donnell, S., 1997. Headquarters Use of Monitoring, Incentives and Normative Control in the Foreign Subsidiary: The Role of International Interdependence in an Agency Theory Framework. University of South California Ph.D. Dissertation.

Pan, Y., 2002. Equity ownership in international joint ventures: the impact of source country factors. Journal of International Business Studies. 33, 375-384.

Pfeffer, J.,and Salancik, G. 1978. The external control of organizations: A resource dependence perspective, New York, Harper \& Row.

Root, H., 1996. Corruption in China: Has it Become Systemic? Asian Survey, 36, 8, 741 757 
Siegel, J. Licht, A. and Schwarts, S., 2006. Egalitarianism, Cultural Distance, and FDI: A New Approach. Social Science Network Electronic Paper.

Smarzynska, B. and Wei, S., 2002. Corruption and Cross-border Investment: Firm-level Evidence. William Davidson Institute Working Papers Series No. 494.

Tekin-Koru, A., 2006. Corruption and the ownership composition of the multinational firm at the time of entry: evidence from Turkey. Journal of Economics and Finance. 30, $2,251-269$

Teng, B., 2004. The WTO and Entry Modes in China. Thunderbird International Business Review. 46, 4, 381-400.

Tihanyi, L. Griffith, D. and Russell, C., 2005. The effect of cultural distance on entry mode choice, international diversification, and MNE performance: a metal-analysis. Journal of International Business Studies. 36, 3, 270-283.

Uhlenbruck K. Rodriguez, P., Doh, J. and Eden, L., 2006. The Impart of Corruption on Entry Strategy: Evidence from Telecommunication Projects in Emerging Economics. Organization Science. 17, 3, 402-414.

Wu, S., 2006. Corruption and cross-border investment by multinational firms. Journal of comparative economics. 34, 839-856.

Zhao, H., Luo, Y., and Suh, T., 2004. Transaction cost determinants and ownership-based entry mode choice: a meta-analytical review. Journal of International Business Studies, $35,6,524-544$. 